\title{
EXPERIENTIAL-LEARNING IN WRITING CLASS: A SUGGESTED TEACHING PRACTICE FOR ISLAMIC UNIVERSITIES
}

\author{
Ani Meitikasari \\ Institut Agama Islam Negeri Metro, Lampung \\ E-mail: animei16@yahoo.co.id
}

\begin{abstract}
In global era, mastering language skills as a means for communication, which focus not only on "transmitting knowledge or cognitive aspects" but also "experiencing authentic-language" based on the context, becomes a fundamental demand for all of language learners in certain educational settings as well as writing skills. The ability in producing a scientific writing by considering the context and aspects of writing is very crucial for higher education students. Therefore, this research, which is an ethnographic classroom study in form of reflective-qualitative point of view, is intended to investigate and design teaching Instruction by using Experiential Learning (EL) in writing class especially for 110 - the second semester students of English Education Department at one of Islamic state universities in Lampung. The data was analyzed based on participant observation during eight-weeklearning meetings, reflective journals, and field notes. In summary, EL may be effectively implemented as an alternative method in writing class by considering some essential points and contexts.
\end{abstract}

Keywords: Experiential Learning (EL), Reflective-qualitative Study, Writing Skills,

\section{INTRODUCTION}

Nowadays, the recent issues dealing with English as a foreign language grow rapidly and comprehensively. The focus not only refers to the nature of language itself but also extends to the application in education settings. These goals maintain the focuses of teaching learning process that should be considered by the teacher in teaching English: learning activities emphasize not only on how the students understand the content (function of the language) but also how the students are able to apply language as a means for communication by considering their social context and psychological learning factors.

Moreover, specifically, the recent issue about mastering language skills as a means for communication especially written form grows rapidly. Weigle (2002: 1) also maintains that writing plays an important role for the students in today's global era. It indicates that the language learner especially in higher education is supposed to be able to master communicative competence in order to achieve better life dealing with academic and carrier aims; the higher students are prepared to practice how to express and report their ideas or experiences into a scientific writing by giving the supporting evidences.

However, in reality, writing still becomes complex language skills, in which the students especially in higher education face some difficulties such as the learning process has been not occurred in interesting and meaningful way as a means for communication; having a real experience about how language is used in daily life, investigating the recent writing topic critically, constructing cooperatively their own understanding about the concepts of various kinds of scientific writing, and communicating those based on the context properly. 
In other words, Richards (1994: p. 97) as cited in Anisa (2013) states "Teachers have primary responsibility for how they teach; they may assume very different roles within their own classroom. It implies that teacher should provide an appropriate teaching method dealing with the students' problems. Specifically, the term "communicate" as "experiencing language" should be emphasized in learning activities. On other words, it is a demand to provide the students to experience their language ability through an activity in real context rather than just focus on the process of transmitting knowledge (Kolb and Kolb, 2009). It means that students are involved directly in a meaningful learning process in order to increase knowledge, develop skills, and clarify values in the suitable environment for language learning (Association for Experiential Education, 2011. para. 2).

Therefore, by considering the explanation above, this research was conducted to design an appropriate teaching instruction by using Experiential Learning in writing class especially for higher education students at the one of Islamic Universities in Lampung, Indonesia.

\section{THEORITICAL REVIEWS \\ The Nature of Writing}

According to Nunan (2003: 88) states that writing is the mental work of inventing ideas, thinking about how to express them, and organizing them into statements and paragraphs that will be clear to a reader. It indicates that writing refers to the way how the writer, in this case as the students, not only express their ideas but also how they organize or arrange their ideas into paragraphs (written form) so that their purpose of the writing can be delivered well and acceptably to the reader.

Moreover, in relation to written products, Brown (2007: 391) states that: "Written products are often the results of thinking, drafting and revising procedures that require specialized skills. The nature of writing focuses on how to generate ideas, how to organize them coherently, how to use discourse markers and theoretical convention, and put them cohesively into a written text, how to revise text for a clearer meaning, how to edit text for appropriate grammar, how to produce a final product". In other words, writing is more focused on the composition process by considering the steps in producing a writing text and the aspects of writing skills.

Furthermore, Peha (2002: 3) defines that there are some aspects of producing writing that can be stated as criteria in assessing writing skills, as follows:

Idea that is interesting and important. Idea is the main points of what writers are writing about and the reason why the writer wants to write it.

Organization that is logical and effective. Organization deals with the order/sequence of writers' ideas and the way how the ideas move to other ideas.

Voice that is individual and appropriate. It refers to writers' personalities through words. Word choice that is specific and memorable. It means that good writing uses the appropriate and correct words to express or explain something.

Sentence fluency that is smooth and expressive. The sentences should be understood easily by the reader and they feel enjoy when they are reading it.

Conventions this is correct and communicative. It deals with the consistency of using correct punctuation, spelling, grammar, and etc.

In addition, dealing with teaching writing, it is more than just dealing with handwriting, orthography (spelling system) and punctuation. It is about helping students to communicate real message in an appropriate manner (Harmer, 2004: 34). It means that in teaching writing, the teachers not only focus to teach the students on the cognitive or linguistics aspects of writing but also the communicative and affective aspects 
for delivering and communicating with others, the readers.

Moreover, in higher education, the focus of writing is how the students can write various kinds of scientific writing as well as their practices in thesis writing as the academic requirements for their degree. Therefore, mastering writing skills should be emphasized well based on the context and the learning objectives.

\section{Experiential Learning}

The concepts of Experiential Learning was initially developed by John Dewey (18591952), Carl Rogers (1902-1987), and David Kolb (1939) that refers to "learning through experience", or "learning by doing". Furthermore, Dewey proposes the concept of experiential leaning focusing on the "problem solving and critical thinking" perspectives. Besides, Rogers concludes that experiential learning more "significant" rather than "meaningless" cognitive learning.

In addition, Brown (2000: p. 238) as cited in Anisa (2013) highlights for us that experiential learning is giving the students concrete experiences through which they "discover" language principles by trial and error, by processing feedback, by building hypotheses about language and by revising these assumptions in order to become fluent in producing a language. It indicates that Experiential Learning is indirectly a part of students' practice in developing their writing habit by solving the writing problem during learning process.

Moreover, Kolb focuses on the concrete learning experience can emphasize to a meaningful learning in which the students involved in the pedagogical process. Kolb (1984: 41) also notes that Experiential Learning is "the process whereby knowledge is created through the transformation of experience. Knowledge results from the combination of grasping and transforming experience." Dealing with the learning cycle of Experiential Learning, here are the proposed by Kolb (1984) as cited in Komalasari (2013, p. 25):

Furthermore, Baker, Jensen, and Kolb (2002) cited in Mollaei, F. and Rahnama, H. (2012: 4) renew the construct of learning cycle, as follows:

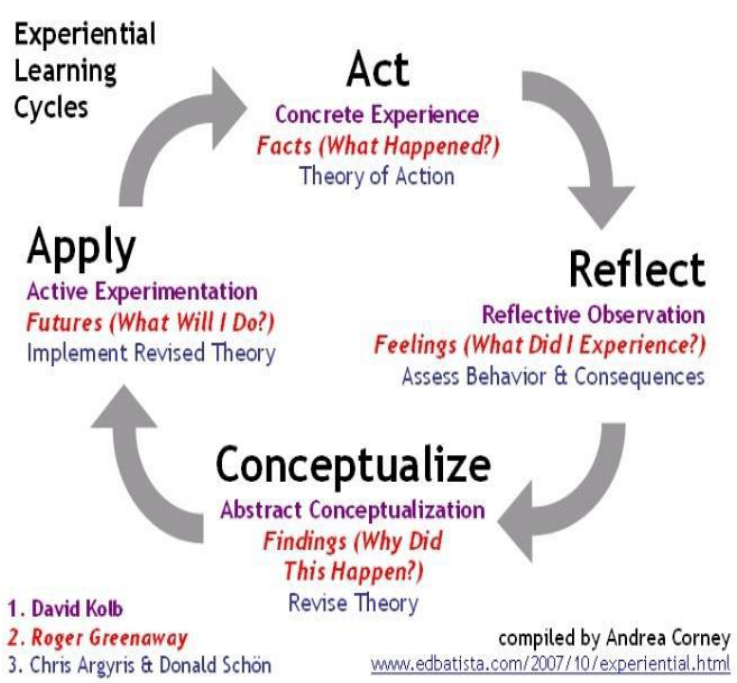

Figure .1. The Experiential Learning Cycle by Kolb (1984)

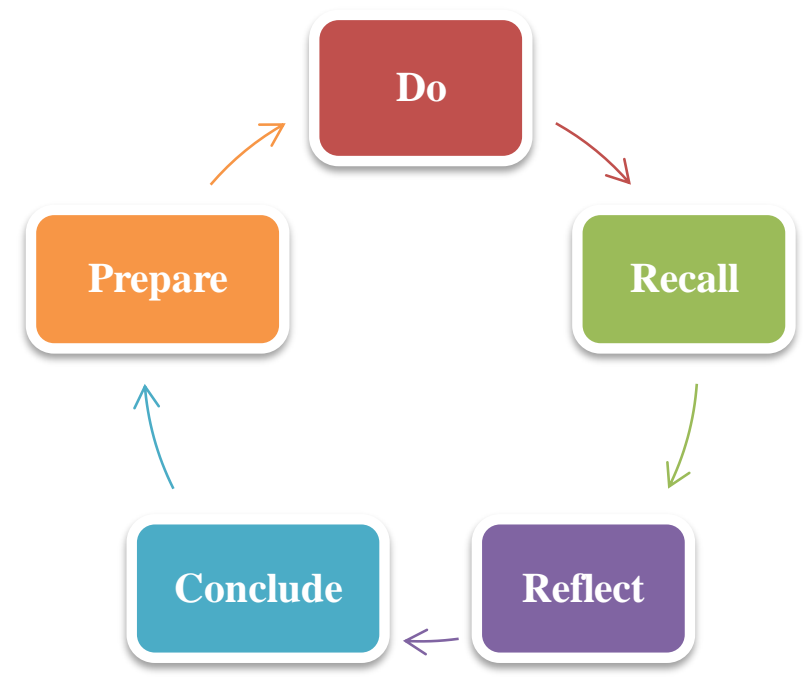

Figure .2. The Experiential Learning Cycle by Baker, Jensen, and Kolb (2002)

Therefore, the process of learning involves those steps:

1. Doing something,

2. Recalling what happened,

3. Reflecting on that, 
4. Drawing conclusion from reflections, and

5. Using those conclusions to inform and prepare for future practical experience.

In 2000, Boud, Cohen and Walker (p. 8-

14) develop five "propositions" about experiential leaning, as follows:

1. Experience is the foundation of, and the stimulus for all learning,

2. Learners actively construct students' own experience,

3. Learning is a holistic process,

4. Learning is socially and culturally constructed

5. Learning is influenced by socioemotional context in which it occurs.

\section{RESEARCH METHODS}

This research is an ethnographic classroom study in form of reflective-qualitative point of view because it attempts to draw up the phenomena naturally happened in routine-in class-interactions in period of a semester between the teacher as a researcher and the second semester students of English Education Department that consists of 110 students.

Moreover, it was conducted in an Islamic university located in Lampung, Indonesia. The researcher collects the data by using participant observation during eightweek-learning meetings, reflective journals, and field notes during the implementation of Experiential Learning in writing class especially for Descriptive and Argumentative Essay. It means that the researcher would observe and analyze the current problems and its causes happened in writing class that was faced by the students, then, those gained data would be used to design the teaching instruction to implement EL by finding out the related literature. Moreover, during eightweek-learning meetings, the researcher conducted EL for writing class and drawn the phenomenon up happened in real teaching activity naturally by participant observation and field notes. Then, the researcher would sum the conclusion up based on the gained data and related journals in order to reflect and describe briefly the real implementation of EL in writing class.

\section{FINDINGS AND DISCUSSION}

\section{Factors Affecting the Learning Process in Writing Class}

Before conducting the Experiential Learning in writing class, the researcher has been observed and reflected writing learning activities for twelve months.

There are some crucial points that should be considered, as follows:

a. Specifically for writing skills, the process of language learning is not apparently adequate for transmitting knowledge; however, it needs more meaningful practices in a real context comprehensively.

b. Writing as a productive language skills demands newest-issues for producing a written text based on the socialcommunicative context.

c. The students' awareness about the aspects of writing which deals with content, organization, vocabulary, language use, and mechanics would lead them up to compose an acceptable and good writing.

d. In order to generate writing ideas, having a real experience of language use is a crucial consideration.

e. The engagement of language learners would guide them at developing their critical thinking and autonomous learning in investigating and constructing the real language use especially in written form.

f. The students' psychological factors during learning activities should be noticed attentively.

g. Dealing with social-cultural context in which learning activities takes place, the Islamic values should be integrated comprehensively. 


\section{Implementation of Experiential Learning in Writing Class}

In this section, the implementation of Experiential Learning would be integrated with the results of participant observation and filed notes by considering authenticlanguage context and Social-Islamic context as noticed for Islamic Universities which the research took place in. Here are the following steps that comprise experiential learning in writing class, as follows:

\section{Experiencing/ Exploring "Doing"}

In this part, the students performed or did a hands-on minds-on experience as an initial language input based on the topic of writing. For descriptive essay, they conducted outdoor learning games in a group work about what they want to describe then, such as guessing picture games. It was expected that they would be introduced the common words used in descriptive essay and constructed their understanding indirectly about descriptive essay.

Moreover, dealing with argumentative essay, the students also conducted outdoor learning activities such as a pro-cons debate dealing with Islamic recent issues. The teacher showed some puzzledebatable pictures about Islamic theme, then, asked them to arrange it and thought their opinion (one group became pro and others would be cons) by piecing out the theoretical concept about it.

Furthermore, having a real experience in outside the class, significantly, drove their self-autonomous learning and interest up about the writing material. Also, by directing them in group work, it would guide them to learn a social relationship cooperatively and support each other to achieve certain goals. In other words, it would refer to Islamic context in which each mankind should help others.

\section{Sharing / Reflecting "What Happened?"}

After having a meaningful experience dealing with the writing material, then, the students asked to write those authentic experiences in a piece of paper and shared the results, reactions and observations with their peers. In this cases, the students allowed to reflect and explored their ideas and feeling during their experience in outdoor learning in order to generate the main points of what they has been discovered and related it to the past experiences which can be applied for future use.

Furthermore, in this part, the learning process occurred cooperatively with peers. It indicated that this activity indirectly would guide them to have self-confidence and selfefficacy in communicating their feeling and minds properly and acceptably. On other words, it can be stated as a real-social practice to recognize the real meaning of communication in simple way. Moreover, the role of the teacher as a facilitator becomes crucial especially how to guide the students can reflect and explore their ideas bravely and feeling honestly and as well as the Islamic Guidelines in real life.

\section{Processing /Analyzing "What's Important?"}

The main point of Experiential Learning is how the students construct their own understanding by having real experiences. Therefore, in this part, the students began to analyze and generate their ideas about the basic principle of writing material; argumentative and descriptive text; based on their experiences before. They worked in a group by answering some questions dealing with the kinds of the writing text such as (a) Based on your opinion and previous experience, what is exactly Argumentative and descriptive text?, (b) What are the functions of those texts?, and (c) What are the aspects that must be considered in producing those texts?, etc. 
By answering those questions cooperatively in a group work, they would have an opportunity to explore their own understanding in order to generate the main point of writing material that would be learned. In other words, they would have schemata about its material and, of course, it would strengthen their concept about argumentative and descriptive text.

Table 1. Questions in a group work

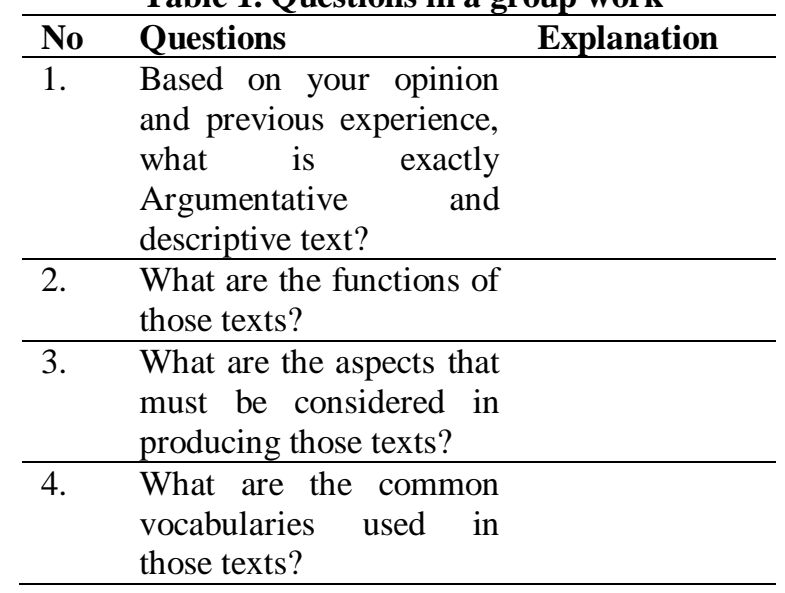

The first question deals with the definition of descriptive text which is constructed from guessing picture games and an argumentative text taken from pro-cons debate dealing with Islamic recent issues by using puzzle-debatable pictures. Then, the second question is about the function of those texts and the third question deals with the indicators/aspects in composing those texts refers to their reflection after finishing those games that have been shared in the second step of experiential learning. Next, the last question deals with the vocabulary that usually applies in those texts as the analysis results of their previous experience about puzzle-picture games.

Furthermore, this learning activity encourages the students' ability in generating and constructing their own ideas confidently, sharpens their critical thinking comprehensively in analyzing the realmeaningful experiences that they have done, and also supports each other cooperatively in finishing the group work.

\section{Generalizing "So What?"}

After analyzing the concepts by reflecting their experience, in this part, the teacher reinforced and convinced the students' understanding about the concepts of those texts especially the aspects of composing texts and the common-scientific vocabulary used in the text.

The next step is brainstorming phase in which the teacher asked them to link it up with the experience with real world examples, found trends or common truths in the experience, and identified "real life" principles that emerged. In this case, the students were allowed to conduct a direct observation completed by the documentation in outside the class; it could be done individually or in a group work; to search for the problem/topic they interest in referring to Islamic context. Here were some observation questions that should be filled by the students, as follows:

Table 2. Observation Questions

\begin{tabular}{|c|c|c|}
\hline No & Questions & Explanation \\
\hline 1 & $\begin{array}{l}\text { Based on your } \\
\text { observation, what is the } \\
\text { problem/issue } \\
\text { interest in? }\end{array}$ & \\
\hline 2 & $\begin{array}{l}\text { Why did you choose this } \\
\text { problem/issue as your } \\
\text { topic? }\end{array}$ & \\
\hline 3 & $\begin{array}{l}\text { What are your purposes } \\
\text { by writing this topic? }\end{array}$ & \\
\hline 4 & $\begin{array}{lr}\begin{array}{l}\text { Explain about } \\
\text { feelings }\end{array} & \text { your } \\
\text { during } \\
\text { obnducting } \\
\text { observation? }\end{array}$ & \\
\hline
\end{tabular}

Those questions were related with the basic reasons in choosing the writing topic; it means that before composing the texts, it demands to have a great foundation why the writer should communicate their ideas to others by investigating the real problem happened currently in real life. In other words, the students were trained to find out newest-issues for producing a scientific written text based on the socialcommunicative context. It also leads them up 
to think critically and analyze autonomously about the problems in real life, therefore, they can do a plan in advance for their scientific thesis as one of the academic requirements in accomplishing their degree.

Moreover, the last questions lead them up to express their feelings during learning activity, therefore, the teachers could also observe their psychological learning aspects and redesign the next-more appropriate learning activities.

\section{Application "Now What?"}

The final step is applying what they learned in the experience (and what they learned from past experiences and practice) to a similar or different situation. They were asked to compose those texts by considering the contexts and the aspects of good writing.

\section{Do's and Don'ts in Applying Experiential Learning for Writing Class.}

By reflecting the implementation of Experiential Learning, there are the following points that should be considered by the teachers in order to achieve learning goals:

\section{Do's Experiential Learning in Writing Class}

a. The initial input of language use in context may use some alternative ways that students involve directly in such as providing authentic materials e.g. newspaper or magazine to find out the proper puzzle-pictures for descriptive texts, presenting the audio-visual aids or conducting outdoor learning games e.g. role play and simulation dealing with the argumentative issues.

b. Even though, the outdoor learning can be used to lead the students' interest and self-efficacy up, however, in choosing those activities should be based on the real condition of the students and its context. c. Discussing cooperatively in group work, indirectly, guides them to support each other especially in constructing their concepts of those texts and its vocabularies used frequently. Therefore, the teacher should encourage them to participate actively.

d. Students' awareness about the aspects of good writing becomes a crucial point during composing those texts, so that, in the "generalizing" step, it should be emphasized clearly by the teachers.

e. Leading the students' feeling up during learning activities may influence the successful learning activities especially in "sharing and reflecting" step.

\section{Don'ts Experiential Learning in Writing Class}

a. In experiencing the language, it may spend much learning time, therefore, the teacher has to avoid an "abstract-theme" experience.

b. The discussion phase, sometimes, becomes uncontrolled and enough noisy because of having different opinion.

c. In composing a text, the writing text will be assessed based on the aspects of good writing. Therefore, it is better if the students focus intensively on the process of writing rather than the writing product hastily.

d. Because of having different point of views, therefore, teachers should avoid a complex-misinterpreted issue.

Therefore, based on the findings, Experiential Learning that deals with the construction process of knowledge, clarify values, and engage the students' participation by providing the students with the meaningful experience may be implemented as an alternative-writing teaching method especially for Islamic University students'. It is also in line with Kohonen (2001) as cited in Mollaei, F. and Rahnama, H., (2012) that Experiential Learning leading the students to 
gain a meaningful learning by focusing on the learning process (UC Davis, 2011).

Moreover, Kolb (2014) maintains Experiential Learning as a holistic process of learning that can aid in overcoming the difficulties of learning from direct experience by helping the process how experience is transformed into learning and reliable knowledge and affecting by emotional states. Therefore, it refers how the students are directly involved in a real-meaningful experience of language use in the certain context as language input, formulate it critically into their own understanding and applied it into a piece of scientific writing text. It is also supported by Nation (2009: 60) who stated that in Experiential learning, students can develop communication skills in the real-context of language use, gain knowledge, and strengthen decisions-making skills by responding to and solving real world problems and processes.

Additionally, working cooperatively in solving the group problem can be functioned as a peer-reviewing of using a certain systematical structure (punctuation and spelling) in the text writing and a practice to communicate their ideas autonomously and confidently to others.

Furthermore, dealing with Islamic context, it refers not only to the writing issues/topics that should be appropriately generated with Islamic-recent issues but also the learning process that contains the Islamic moral value. In this case, Experiential Learning reflects how the students should be socially involved in learning process such as being respectful each other in discussion phase, thinking sensitively about the problems in real life during an observation phase, and applying their construct to produce an acceptable-scientific writing text.

\section{CONCLUSION}

In teaching writing, one of the teachers' responsibilities is conducting the teaching learning process effectively and wellprepared by considering the students' interest and situation in order to achieve learning goals in writing skills. Therefore, implementing Experiential Learning is supposed to be an alternative way to teach writing for Islamic university students.

\section{REFERENCES}

Association for Experiential Education http://www.aee.org/

Boud, D., Cohen, R. and Walker, D. (2000). Using Experience for Learning: Understanding Learning From Experience Milton Keynes: SRHE/Open University Press.

Graham, S. Executive control in the revising of students with learning and writing difficulties. (1997). Journal of Educational Psychology, Vol. 89(2), pp.223-234.

Ike, Annisa. (2013). Experiential Learning In Teaching English. Magistra No. 85 ISSN 0215-9511

Joyce, B., Weil, M., \& Calhoun, E. (2000). Models of teaching (6th eds.). Boston: Allyn \& Bacon.

Komalasari, Adesti. (2013). Employing Experiential Learning to Teach Writing for English as a Foreign Language Learners Through a Reflection Project. International Journal On Education. Vol.1, No.1

Kohonen, V. Towards experiential foreign language education. (2001). In Kohonen, V., R. Jaatinen, P. Kaikkonen and J. Lehtovaara, Experiential learning in foreign language education. London: Pearson Education, 8-60.

Kolb, D. A. (1984). Experiential learning: Experience as the source of learning 
and development. Upper Saddle River, NJ: Prentice Hall.

Meitikasari, Ani. (2016). Experiential Learning (EL): An Effective Teaching Method To Construct Students' Writing Skill Viewed From Self-Efficacy. Proceeding International Conference of Teacher Training and Education, FKIP UNS 2015. Vol 1, Nomor 1, ISSN: 25024124

Mollaei, F. and Rahnama, H. (2012). Experiential Education Contributing to Language Learning. International Journal of Humanities and Social Science. Vol 2 No. 21, November 2012. www. ijhssnet.com.

Nation. I. S. P., (2009). Teaching ESL/EFL Reading and Writing. New York: Routledge

Nunan, D. (2003). Practical English Language Teaching. Singapore: Mc Graw Hill.

Sharlanova, V. (2004). Experiential Learning. Trakia Journal of Sciences, Vol 2, No. 4, pp 36-39,. www.unisz.bg

Slavin, Robert E.,. (2006). Educational Psychology Theory and Practice. New York. Pearson Educations Inc.

Smith, M. K. David A. (2001). Kolb on Experiential Learning. Encyclopedia of Informal Education, 1-15. Retrieved from http://www.infed.org/b-explrn.htm. .

University of California Davis (UC Davis). (2011). Frequently Asked Questions (FAQ). Retrieved from http://www.experientiallearning.ucda vis.edu/faq.shtml 